\title{
Bacteriocidal Properties of Bacillus Subtilis Nanoparticles Against Selected Human Pathogens
}

\author{
A. O. Daniels, J. K. Fadairo, and A. O Fashoyin
}

\section{ABSTRACT}

The use of biologically synthesized nanoparticles has been an area of research interest in recent times. Due to the high rate of bacterial resistance to antibiotics, there is a need to search for a more potent alternative to ineffective antibiotics. This study aims to evaluate the antibacterial effects of silver nanoparticles synthesized by Bacillus subtilis against Pseudomonas aeruginosa and Staphylococcus aureus. Silver nanoparticles were obtained by dissolving 0.842 gram of $\mathrm{AgNO}_{3}$ silver nitrate into $100 \mathrm{ml}$ of $B$. subtilis in Mueller Hinton broth. The antibacterial susceptibility of the nanoparticles formed was carried out using standard methods. Comparative antibacterial test was also carried out using standard antibiotics The multiple antibiotic resistance index were also determined. The zones of inhibition were 29 and $12 \mathrm{~mm}$ against Staphylococcus aureus and Pseudomonas aeruginosa respectively after $8 \mathrm{hrs}$ of nanoparticle synthesis. The antibiotic susceptibility test using standard antibiotics revealed that $S$. aureus was sensitive to only Erythromycin and ofloxacin with a zone of inhibition of $15 \mathrm{~mm}$ and $9 \mathrm{~mm}$ respectively while $P$. aeruginosa was sensitive only to ofloxacin. The Multiple resistance index (MARi) shows $P$ aeruginosa to have MARi of 0.9 while $S$, aureus has MARi of 0.82. The result indicated that $B$. subtilis nanoparticles presented better antibacterial properties than standard antibiotic and can be explored as a candidate for drug production to fight bacterial resistance to antibiotics.

Keywords: Antibacterial, nanoparticles, Multiple antibiotic resistance index, Bacillus subtilis.
Published Online: September 17, 2020

ISSN: 2684-5199

DOI : 10.24018/ejbio.2020.1.5.65

\section{A. O. Daniels*}

Department of Biological Sciences

College of Natural and Applied Sciences, Achievers University, Owo, Ondo State, Nigeria.

(e-mail: toyosidanny@yahoo.com)

\section{J. K. Fadairo,}

Department of Medical Laboratory Sciences, College of Natural and Applied Sciences, Achievers University, Owo, Ondo State, Nigeria.

\section{A. O. Fashoyin}

Department of Biological Sciences College of Natural and Applied Sciences, Achievers University, Owo, Ondo State, Nigeria.

*Corresponding Author

\section{INTRODUCTION}

Multidrug resistance among pathogens has become a global problem for the treatment and cure of bacterial infections [1]. There is a need to explore new and alternative avenues for antimicrobials that are less susceptible to microbial resistance. Nanoparticles (NPs) are defined as particulate matter with at least one dimension that is less than $100 \mathrm{~nm}$. [2]. NPs are very effective as antimicrobials and offer better therapy than conventional antibiotics due to the fact that nanoparticles in direct contact with the cell wall without necessarily penetrating the cell wall contrary to the mode of action of most antibiotics [3]-[5]

There is a need to consider the biological synthesis of nanoparticles because it is ecofriendly as compared to other routes of nanoparticle synthesis [6].

Three NPs have found useful in antibacterial therapy which are silver, gold, and copper NPs. Silver nanoparticle (Ag) is known to perforate the cell wall by increasing the, and optical properties [7] Three NPs have found useful on antibacterial therapy which are silver, gold, and copper NPs.

Silver nanoparticle $(\mathrm{Ag})$ is known to perforate the cell wall by increasing the permeability and inactivating the respiratory chain [8].
Nanoparticles have been known to have antimicrobial effect on fungi, viruses, parasites and protozoa also [9] and they also exhibit synergistic tendencies with conventional antibiotics with greater retention time within the system of the host as compared to other drugs [9].

The nanoparticles synthesized by biological process especially microorganisms have higher catalytic reactivity, greater specific surface area and can interact with other microorganisms [10]. The main interest is production of nanoparticles using a biological method however, utilizing a biological source gives an easy approach, easy multiplication, and easy increase of biomass and size uniformity [11].

Silver salts such as silver nitrate $\left(\mathrm{AgNO}_{3}\right)$ are effective at providing a large quantity of silver ions all at once. Because silver binds to thiol groups. Although one of the antimicrobial mechanisms of $\mathrm{Ag}^{+}$is binding efficiently to sulfur-containing compounds in the bacterial surface and rupture their cell wall causing cell death [12]. The downside of this is that thiolcontaining compounds such as proteins with cysteine residues can serve to absorb silver ions and neutralize their antibacterial activity by preventing the silver ions from attacking DNA [13].

Some authors have reported the biosynthesis of gold, silver, gold-silver alloy, selenium, tellurium, platinum, palladium, silica, titanium, zirconia, quantum dots, magnetite 
and uranite, nanoparticles by bacteria, actinomycetes, fungi, yeasts and viruses [14]. Nanoparticles are biosynthesized when the microorganisms target ions from their environment and then turn the metal ions into elemental metal through enzymes generated by the cell activities [15].

Microorganisms that are known to synthesize nanoparticles include, but not limitded to Pseudomonas stutzeri [16]. A. calcoaceticus, B. flexus, B. megaterium, B. amyloliquefaciens, S. aureus and Bacillus strain. [17]-[19]

Biosynthesized nanoparticles have found applications in many procedures including as drug carriers for targeted delivery [20]. Cancer treatment [21], gene therapy and DNA analysis [22], antimicrobial agents [23], biosensors [24], enhancing reaction rate [25], separation science [26], and magnetic resonance imaging (MRI) [27].

The aim of this research is to synthesize nanoparticles from bacteria using silver nitrate and used as antibacterial against selected bacteria.

\section{Methods AND MATERIALs}

\section{A. Preparation and standardization of Bacteria}

The bacteria used include clinical strains of Bacillus subtilis, Pseudomonas aeruginosa and Staphylococcus aureus in this was were collected from the Achievers University Microbiology Laboratory and confirmatory tests were carried out to ascertain the viability of the test organisms using biochemical methods and Gram staining techniques. The bacteria cultures were standardized to the McFarland's constant using $\mathrm{BaSO}_{4}$ according to the procedures described by Cheesebrough (2000).

\section{B. Inocula preparation.}

Bacillus subtilis, Pseudomonas aeruginosa and Staphylococcus were suspended in Mueller Hinton broth. and incubated for 4 hours to obtain a concentration corresponding to McFarlands constant $(0.5 \times 108 \mathrm{cfu} / \mathrm{ml})$. The inocula were standardized with the prepared barium sulphate

\section{Synthesis of Nanoparticles;}

A modified method of [28] was used in the synthesis of nanoparticles from Bacillus subtilis. A 0.842 gram portion of $\mathrm{AgNO}_{3}\left(\mathrm{AgNO}_{3}\right.$, Kermel Nigeria), was added to standardized broth culture of Bacillus subtilis in a test tube and shaken thoroughly using the magnetic shaker (Gallenkamp 23/5861E). The test tube was wrapped with foil paper to prevent oxidation of silver [29] and kept under sterile condition.

$\mathrm{AgNO}_{3}+$ Bacillus subtilis $=\mathrm{AgNp}$ Bacillus subtilis

\section{Structural changes in B. subtilis after synthesis of nanoparticles}

After synthesis, Bacillus subtilis was observed under the microscope for structural, physiological or morphological changes as a result of exposure to silver nitrate.

\section{E. Comparative Antibacterial Activity Using Standard Antibiotics.}

The disk diffusion method of [30] was adopted for the standard antibiotics including; Augmentin $30 \mu \mathrm{g}$, Gentamicin $30 \mu \mathrm{g}$, Ceftazidime $30 \mu \mathrm{g}$ Ofloxacin $30 \mu \mathrm{g}$, Erythromycin $30 \mu \mathrm{g}$, Ceftriaxone $30 \mu \mathrm{g}$, Cloxacilin $30 \mu \mathrm{g}$, Ceflaxone $30 \mu \mathrm{g}$, Nitrofurantoin $30 \mu \mathrm{g}$, Ciprofloxacin $30 \mu \mathrm{g}$, and Cefixime $30 \mu \mathrm{g}$, while the agar well diffusion method of [31] was adopted for the testing of B. subtilis nanoparticles against Pseudomonas aeruginosa and Staphylococcus .

\section{F. Multiple Antibiotic Resistance Index (MAR):}

The multiple antibiotic resistance (MAR) index for the bacteria strains used was determined according to the procedure described by Krumperman [32]. The indices were determined by dividing the number of antibiotics to which the organism were resistant to (a) by the number of the antibiotics tested (b), Resistance to three or more antibiotics is taken as MAR index and MAR greater that 0.2 indicates a high level of resistance.

\section{G. Statistical Analysis}

The statistical analysis was carried out using SPSS (Statistical Package for Social Science) version 20, to test the level of significant at $5 \%$ level of confidence. The antibiotic susceptibility of the test bacteria was compared to antimicrobial activity of Bacillus subtilis of silver nano particle on both Staphylococcus aureus and Pseudomonas aeruginosa using T-Test.

\section{RESULT AND DISCUSSION}

\section{A. Physical observation of culture during synthesis.}

At inoculation, the culture of B. subtilis presented yellow colouration, When $\mathrm{AgNO}_{3}$, was added, there was a colour change from yellow to brownish yellow and after 2 hrs of incubation, there was a colour change to brown which was consistent throughout $8 \mathrm{hrs}$ of incubation evidencing the synthesis of nanoparticles. Presupposing that nanoparticles formation started after $2 \mathrm{hrs}$ of synthesis.

B. Microscopic observation of B. subtilis after synthesis of nanoparticles.

There was no damage to the morphological feature of the cells of $B$. subtilis after synthesis when viewed under the microscope. The Gram status also remained as positive.

\section{Physical appearance of nanoparticles on agar plate.}

The plates presented a silver coated surface which could be attributed to the silver nanoparticles. Figures $1 \mathrm{a}$ and $1 \mathrm{~b}$ show the agar plates of $B$. subtilis against Pseudomonas aeruginosa and Staph aureus after 8 hrs of synthesis after incubation at $37{ }^{\circ} \mathrm{C}$ for 24 hours. Change of the reaction mixture from pale yellow to brown colour indicated the production of silver nanoparticles $\left(\mathrm{Ag}^{+}\right.$to $\left.\mathrm{Ag} 0\right)$ [33] The appearance of brown colour in $\mathrm{AgNO}_{3}$ treated flask can be attributed to the surface Plasmon resonance (SPR) suggestive of the formation of AgNPs [34].

A brownish colouration was observed around the zones of inhibitions of the silver nanopaticules synthesis and for both test organisms, however the $S$. aureus had a shiny silver colouration within the zones of inhibition between 7 to the 8 hour of synthesis after incubation at $37^{\circ} \mathrm{C}$ for 24 hours. 


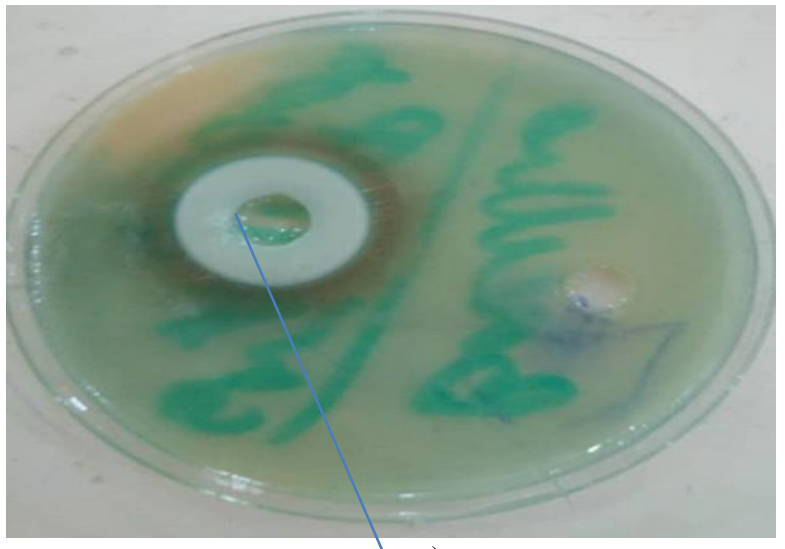

a)

Zone of inhibition showing silver Coating of $\mathrm{AgNO}_{3}{ }^{+}$ nanoparticles

r

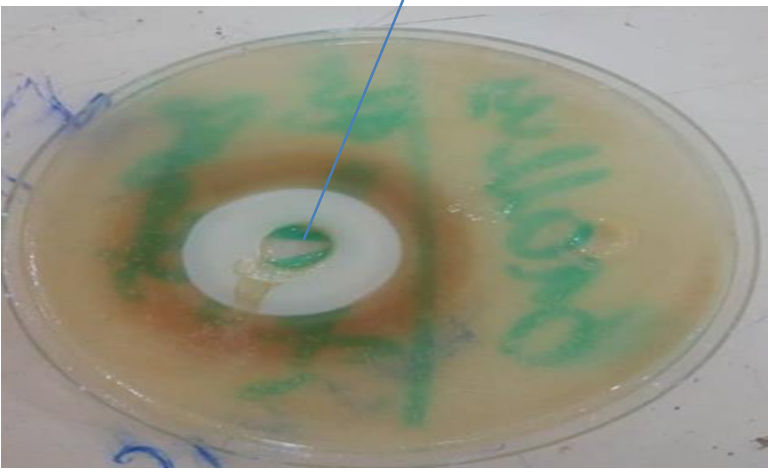

b)

Fig. 1 a, b. Zones of inhibition of silver nanoparticles synthesized from B. subtilis against $\mathrm{P}$. aeruginosa and $\mathrm{S}$. aureus respectively.

\section{Antibiotic Susceptibility}

The comparative antibiotic susceptibility test using standard antibiotics disc showed that Ofloxacin, ciprofloxacin, were effective against Staphylococcus aureus and Pseudomonas aeruginosa and with zones of inhibition ranging from $4 \mathrm{~mm}$ to $15 \mathrm{~mm}$ while Bacillus subtilis silver nanoparticles (BsAgNp) had zones of inhibition of 12 and $29 \mathrm{~mm}$ against $P$. aeruginosa and $S$. aureus respectively as presented in Table 1.

TABLE 1: THE ANTIMICROBIAL ACTIVITIES OF STANDARD ANTIBIOTICS AND SILVER NITRATE AGAINST TEST BACTERIA

\begin{tabular}{lll}
\hline & Zones of inhibition in mm \\
\hline Antibiotics & P. aeruginosa & S. aureus \\
Ofloxacin & 10 & 4 \\
Augmentin & - & - \\
Gentamicin & - & 4 \\
Ceftazidime & - & - \\
Nitrofurantoin & - & - \\
Ceftriaxone & - & - \\
Ciprofloxacin & 4 & 3 \\
Cefixime & - & - \\
Erythromycin & - & 15 \\
Cloxacilin & - & - \\
BsAgNp & $\mathbf{1 2}$ & $\mathbf{2 9}$ \\
\hline
\end{tabular}

BsAgNp - Bacillus subtilis silver nanoparticles.

The antibiotic susceptibility interpretation chat according to [35] reported that values less than $9 \mathrm{~mm}$ for antibiotics is considered resistant. So the test organism can be said to be resistant to the standard antibiotics used. The problem of antibiotic resistance of microorganisms has posed a serious and immense global challenge. Most of the currently available antimicrobials which are synthetic are inefficient and some elicit adverse side effects [36]-[37] The use of antibiotics over the years has led to numerous hazards to public health where some infection do not respond to any existing drugs [38]. This is evident with the level of resistance recorded as shown above.

\section{E. Multiple antibiotic resistance index (MARi)}

The multiple antibiotic resistance index of Pseudomonas aeruginosa and Staphylococcus aureus is presented in Table 2. P. aeruginosa has MAR index of 0.9 and the same value was recorded for $S$. aureus. Bacteria having MAR index of $\geq 0.2$ indicates a high level of multi drug antibiotic resistance. The result thus presented confirms the high level of resistance of these two organisms to standard antibiotics.

TABle 2: MultiPLE ANTIBIOTIC RESISTANCE INDEX FOR P. AERUGINOSA

\begin{tabular}{ll}
\multicolumn{2}{c}{ AND S. AUREUS } \\
\hline Test bacteria & MARi \\
\hline P. aeruginosa & 0.9 \\
S. aureus & 0.82 \\
\hline
\end{tabular}

\section{F. Antibacterial activity of $B$. subtilis nanoparticles} against test bacteria

Antimicrobial assessment of the synthesized nanoparticles was carried out on test bacteria hourly during synthesis and the values recorded. Interestingly, the nanoparticles synthesized by Bacillus subtilis showed appreciable antibacterial actions as compared to the antibiotics used. The activity of $B$. subtilis nanoparticles is presented in Table 3. The activity is time dependent as more efficacy was observed with increase in time of synthesis with the highest activity recorded at the $8^{\text {th }}$ hour of synthesis.

TABLE 3: ANTIMICROBIAL ACTIVITY OF BACILLUS SUBTILIS SILVER NANOPARTICLES ON TEST BACTERIA

\begin{tabular}{ccc}
\hline \multirow{2}{*}{ Time in hrs } & \multicolumn{2}{c}{ Zone of inhibition in mm } \\
\cline { 2 - 3 } At inoculation (0hr) & $5.5 \pm 0.7$ & P. aeruginosa \\
1 & $9 \pm 0 \pm 0.7$ \\
2 & $11.5 \pm 0.7$ & $5 \pm 0$ \\
3 & $12.5 \pm 0.7$ & $6 \pm 0$ \\
4 & $16 \pm 0$ & $7 \pm 0$ \\
5 & $17.5 \pm 0.7$ & $7.5 \pm 0.7$ \\
6 & $20 \pm 0$ & $8.5 \pm 0.7$ \\
7 & $23 \pm 0$ & $10 \pm 0$ \\
8 & $29 \pm 0$ & $11 \pm 0$ \\
& & $12 \pm 0$ \\
\hline
\end{tabular}

Comparatively, the activity of nanoparticles synthesized from $B$. subtilis was significantly better $(\mathrm{P}<0.05)$ than standard antibiotics. The level of bacterial resistance to antibiotics is evident in the result presented in table 1 . The high level of resistance is not surprising, given the notoriety of $P$. aeruginosa.

$P$. aeruginosa, known to cause infection in patients with compromised immune system and it is usually involved in nososcomial infection [39]-[41]. Report has also shown this organism to be resistant to a number of antibiotics [42]. On the other hand, $S$. aureus showed better susceptibility to the nanoparticles than $P$ aeruginosa (Table 1). S. aureus is also known to have acquired multiple antibiotic resistance to various antibiotics [43], [44]. Various microorganisms have 
developed drug resistance over many generations as a result of genetic mutation, misuse or overuse of antibiotics, wrong prescription and other related factors. However, several authors have described Ag ions and Ag based compounds as having strong antimicrobial effects [45] which can be explored as alternatives to ineffective antibiotics.

The obvious activity of Silver nanoparticle suggests that it could be used as an effective antibacterial against $S$. aureus and $P$. aeruginosa which are culprits in a number of diseases such as chronic wound infections, respiratory infections and other Staphylococcal infection. .Silver ions in particular have been shown to exert strong inhibitory and antibacterial effects as well as to possess a broad spectrum antimicrobial property [46], [47] [49]; [6] in their work reported that silver nanoparticles have potent antibacterial activities against $S$. aureus and E. coli. [50] showed that silver bio-nanoparticles from bacteria have inhibitory and bactericidal effect against Methicillin- Resistant Staphylococcus aureus (MRSA). The mechanism of inhibitory action of silver ions on microorganisms is not completely known. It is believed that DNA loses its replication ability and cellular proteins become inactivated with $\mathrm{Ag}+$ treatment. also, it was recorded that $\mathrm{Ag}+$ may likely binds to functional groups of proteins, resulting in protein denaturation of microbes [51].

The first evidence of bacteria synthesizing silver nanoparticles was established using the Pseudomonas stutzeri AG259 strain that was isolated from silver mine. Some microorganisms can survive metal ion concentrations and grow under those conditions due to their resistance to that metal. The mechanisms involved in the resistance are the efflux systems, alteration of solubility and toxicity via reduction or oxidation, biosorption, bioaccumulation, extracellular complex formation or precipitation of metals, and lack of specific metal transport systems [52].

The application of antibacterial nanotechnology is fast gaining importance in the prevention of devastating consequences of antibiotic resistance. The basic properties of nanomaterials make them good candidates as antimicrobials [53]. Nanotechnology today offer promising future as alternative to antibiotics in the control of bacterial infections as a result of their prolonged antimicrobial activity coupled with low toxicity as compared to antimicrobial agents that display short term activity, high toxicity and side effects.

\section{CONCLUSION}

There are strong needs for the development for new and novel antimicrobial agents that are less toxic, less expensive with lesser or no side effect and the exploration of nanotechnology is an option to be closely invested in. Sources like bacteria and plant materials can be looked into as sources of nanoparticles in combating resistant bacteria.

\section{REFERENCES}

[1] F. AbdulQuais, A. Shafiq. F.M. Husain, R.A. Khan, B. Alenazi, A.A.salme and I. Ahmad. Antibacterial effect of silver nanoparticles synthesized using Murray Koenigii (L0 against multidrug resistant pathogens. Bioorganic Chemistry and Applications. 2019. Article ID 4649506, 11 pages.

[2] SCENIHR. Request for a scientific opinion on the Appropriateness of existing Methodologies to assess the potential Risk Associated with Engineered and adventitious Nanotechnologies. SCENIHR/02/05. Brussies European Commission. Scientific committee on emerging and newly identified health risks.

[3] S. Shahzadi, N. Zafar and R. Sharif. Antibacterial activity of metallic nanoparticles. Antibacterial Activity of Metallic Nanoparticles, Bacterial Pathogenesis and Antibacterial Control, Sahra, IntechOpen, DOI: 10.5772/intechopen.72526. Available from: https://www.intechopen.com/books/bacterial-pathogenesis-andantibacterial-control/antibacterial-activity-of-metallic-nanoparticles 2018.

[4] K. M. Varie, M. Gudeppu, A. Chinnasamy, S. Thangarajan, J. Balasubramanian, Y. Li, B. Gajendran. Nanoparticles: Antimicrobial Applications and Its Prospects. Advanced Nanostructured Materials for Environmental Remediation pp 321-355. 2019.

[5] L. Wang, C. Hu, L. Shao. The antimicrobial activity of nanoparticles ; Present situation and prospects for the future. International Journal of Nanomedicine. 12, 1227-1249 2017, 2014.

[6] S. N. Zafar and R. Sharif. Antibacterial activity of metallic nanoparticles. Bacterial Pathogenesis and Antibacterial Control. 2018. Sahara Intech Open. DOI;1057726.

[7] P. Thuesombat, S. Hannongbua, S. Akasit, and S. Chadchawan, "Effect of silver nanoparticles on rice (OryzasativaL. cv.KDML 105) seed germination and seedling growth," Ecotoxicology and Environmental Safety, vol. 104, pp. 302-309, 2014.

[8] Y. Houri-Haddad, A. Domb, W. Khan, and R. Hazan. Alternative Antimicrobial Approach: Nano-Antimicrobial Materials. EvidenceBased Complementary and Alternative Medicine Volume 2015, Article ID $246012,2015$.

[9] A. Khezerlou, M. Alizadeh-Sani, M. Azizi-Lalabadi, Microbial pathogenesis. Elsevier (123), 2018, Pages 505-526.

[10] W. Seo, S. Lee, J.H. Sun, X, Suzuki, Y. Mann Z. Liu and M. Terashima. FeCo/graphitic-shell nanocrystals as advanced magneticresonance-imaging and near-infrared agents. Natural Materials; 5: 12: 976-6. 2006.

[11] A. Chokriwal, M. M. Sharma, A. Singh. Biological Synthesis of Nanoparticles using Bacteria and their Applications. 2014. American Journal of Pharmtech Research. 2014; 4(6).

[12] L. Wang, C. Hu, L. Shao, The antimicrobial activity of nanoparticles: present situation and prospects for the future, Int. J. Nanomedicine 12 (2017) 1227.

[13] S. Y. Liau, D. C. Read, W. J. Furr and A. D. Russell. 'Interaction of silver nitrate with readily identifiable groups relationship to the antibacterial action of silver ions" Letters in Applied Microbiology,1999 25 (4) pp. 279-283.

[14] K. B. Narayanana, and N. Selvaraj. Biological synthesis of metal nanoparticles by microbes. Digest Journal of Biostructure. 2010. 5 (1); 135-140.

[15] X. Zhang, L. Alexander, G. C. Hegeri, P. Jones, T. Peterson, B. G. Trewin and Z. Wiers. Synthesis of nanoparticles by microorganisms and their application in enhancing microbiological reaction rates. Chemosphere, 2011. 82(4): p. 489-494.

[16] T. Klaus, R. Joerger, E. Olsson, C.G. Granqvist (1999) Silver-based crystalline nanoparticles, microbially fabricated. Proc Natl Acad Sci USA 96:13611-13614.

[17] A. Nanda and M. Saravanan. Extracellular synthesis of silver bionanoparticles from Aspergillus clavatus and its antimicrobial activity against MRSA and MRSE'. Journal of Biotechnology. 77: 214- 218. 2010.

[18] A. S. Reddy, C. Y. Chen., C. C. Chen, J. S. Jean., C. W. Fan., H. R. Chen., J. C. Wang., V. R. Nimje. Synthesis of gold nanoparticles via an environmentally benign route using a biosurfactant. J. Nanosci. Nanotechnol. 2009. 9: 6693-6699.

[19] W. Wei, X. Mao, L.A. Ortiz, D. R. Sadoway. Oriented silver oxide nanostructures synthesized through a template-free electrochemical route. J Mater Chem 21:432-438. 2011.

[20] R.S. Soumya, and P.G. Hela. Nano silver based targeted drug delivery for treatment of cancer. Der Pharmacia Lettre, 2013. 5(4): pp. 189 $197,2013$. 
[21] V. Mulens, M.P/ Morales and D.F. Barber. Development of magnetic nanoparticles for cancer gene therapy: a comprehensive review. 2013 ISRN Nanomaterials.

[22] I. Sondi, and B. Salopek-Sondi. Silver nanoparticles as antimicrobial agent: a case study on E. coli as a model for Gram-negative bacteria. Journal of colloid and interface science, 2004. 275(1): 177-182.

[23] P. Sistani, L. Sofimaryo, Z. R. Masoudi, A. Sayaa, R.Rahimzadeh. A Penicillin Biosensor by Using Silver Nanoparticles. Int. J. Electrochem. Sci.,9 (2014) 6201 -6212. 2014.

[24] B. K, Salunke, S. S, Sawant, S. I, Lee, B. Kim. Comparative study of $\mathrm{MnO} 2$ nanoparticle synthesis by marine bacterium Saccharophagus degradans and yeast Saccharomyces cerevisiae. Applied Microbiology and Biotechnology. 2015. 99(13):5419-27.

[25] E. Guihen and J.D. Glennon. Nanoparticles in separation sciencerecent developments. Analytical letters, 2003. 36 (15): 3309-3336.

[26] B. Blasiak, F.C. Van Veggel and B. Tomanek. Applications of nanoparticles for MRI cancer diagnosis and therapy. Journal of Nanomaterials: 2013. p. 12.

[27] M. Jeyaraj, G. Sathiskumar, G. Sivanandhan, D. Muburakali, R. Arun, G Kapildev, M. Manickkavaagam, Biogenic silver nanoparticles for cancer treatment: an experimental report. Colloids and surfaces B: Biointerfaces, 2013. 106: p. 86-92.

28] M. Mohammad N. Sistani1, A. Montazeri, R. Yazdaniland H Murtomaa New oral health literacy instrument for public health: development and pilot testing. Journal of investigative and clinical dentistry 5(4), 2013

[29] M. Cheesebrough. Microbiological test. District Laboratory Practice in Tropical countries. 2000. pp 1-226,

[30] A. W, Bauer, W. M, Kirby, J. C, Sherris, M. Turck. Antibiotic susceptibility testing by a standardized single disk method. American Journal of Clinical Pathology. 1966 .45:493-496.

[31] R.R. Banala., V. B. Nagati. And P. R. Karnati. Green synthesis and characterization of Carica papaya leaf extract coated silver nanoparticles through X-ray diffraction, electron microscopy and evaluation of bactericidal properties. Saudi Journal of Biological Sciences. 2015. Volume 22, Issue 5, pp 637-644.

[32] S. S. Shankar, A. Ahmad, and M. Sastry. Geranium leaf assisted biosynthesis of silver nanoparticles. , (2003). Biotechnology. Progress, 19, 1627-163.

[33] B. Perez, M. Paul, P. Bazerque Antibiotic assay by Agar-well diffusion method". Biological and medical experiment. pp 113-115. 2006.

[34] P. H. Krumpermann, Multiple Antibiotic Resistance Indexing of Escherichia Coli to Identify High-Risk Sources of Fecal Contamination of Foods. Appl Environ Microbiol. 1983 Jul; 46(1) $165-170$.

[35] C. Ranganath, L. Renata, F. SaDel Fiol and M. Victor. Prospects for the Use of New Technologies to Combat Multidrug-Resistant Bacteria" Frontiers in Pharmacology. 10: 46-57, 2012.

[36] K. Kalishwaralal, S. Ramkumarpandian, D. Venkataraman and H Nellaiah. xtracellular biosynthesis of silver nanoparticles by the culture supernatant of Bacillus licheniformis. .2008. Materials Letters 62(29):4411-4413.

[37] M. R. Saker, K. N. Islam, H. Z. Kuri, M. Raiman. Studies of the Impact of Occupational Exposure of Pharmaceutical Workers on the Development of Antimicrobial Drug Resistance. Journal of Occupational Health 2014. 56: 260-270.

[38] S. F. Van Vuuren, Antimicrobial Activity of South African Medicinal Plants J Ethnopharmacol. 2008 Oct 28;119 (3):462-72. 2008.

[39] L. L Lifongo, F. Ntie-Kang, C. V. Simoben, and A. B. Babiaka. A Bioactivity Versus Ethnobotanical Survey of Medicinal Plants from Nigeria, West Africa. Natural Product Bioprospect. 2014. 4;1-9.

[40] E. A. Palombo, Traditional Medicinal Plant Extracts and Natura Products with Activity against Oral Bacteria: Potential Application in the Prevention and Treatment of Oral Diseases. Evidence based Complementary and Alternative Medicine 2011; |Article ID 680354 15 pages.

[41] B. Khameneh, R. Diab, K. Ghjazvini, and B. S. Bazza, Breakthroughs in Bacterial Resistance Mechanisms and the Potential Ways to Combat Them. Microbial Pathogens 2016. ; 95:32-42. 2016).

42] T. Rasamiravaka, Q. Labtani, P. Duez, M. El Jaziri. The formation of biofilms by Pseudomonas aeruginosa: a review of the natural and synthetic compounds interfering with control mechanisms. Biomedical Research International. 2015; 2015759348. doi 10.1155/2015/759348

[43] F. A. Martinez, J. M. Momingue, A. Converti, R. P. Oliveira, Production of bacteriocin-like inhibitory substance by
Bifidobacterium lactis in skim milk supplemented with additives. Journal of Dairy Research. 2015; 82 (3):350-355.

[44] A. P, Magiorakos, A. Srinivasan, R. B. Carey, Y. Carmeli, M. E. Falagas, C. G. Giske. Multidrug-resistant, extensively drug-resistan and pandrug-resistant bacteria: an international expert proposal for interim standard definitions for acquired resistance. Clinical and Microbiology of Infections. 2012; 18(3):268-81.

[45] M. A. Pfaller, R. N. Jones, G. V. Doern, K. Kugler. Bacteria pathogens isolated from patients with bloodstream infection: frequencies of occurrence and antimicrobial susceptibility patterns from the SENTRY antimicrobial surveillance program (United States and Canada, 1997).

[46] M. Brandon, M.J. Dowzicky. Antimicrobial susceptibility among gram-positive organisms collected from pediatric patients globally between 2004 and 2011: results from the trigecycline evaluation and surveillance trial. Journal of Clinical Microbiology 51 (2013), pp. 2371-2378.

[47] F. Furno , K. S. Morley, B. Wong, B. L. Sharp, P. L. Arnold, S.M Howdley, R. Bayston,, P.D. Brown, P.D. Winship and H.J. Reid. Silver Nanoparticles and Polymeric Medical Devices: A New Approach to Prevention of Infection? 2004. Journal of Antimicrobial Chemotherapy. 54 (6): 1019-1024.

[48] K. Soo-Hwan, L. Hyeong-Seon, R. Deok-Seon, C. Soo-Jae, and L. Dong-Seok. Antibacterial Activity of Silver-nanoparticles Against Staphylococcus aureus and Escherichia coli" Korean Journal Microbiology and Biotechnology. 2011. 39: 77-85.

[49] A. Shahverd, A. Fakhimi, R. Shahverdi, S. Minaian. "Synthesis and effect of silver nanoparticles on the antibacterial activity of different antibiotics against Staphylococcus aureus and Escherichia coli' Journal of Nanomedicine. 2007. 3(2):168-71.

[50] S. Shirley, T. Bera, A. Roy, G. Singh, P. Ramachandrarao and D. Dash. Characterization of enhanced antibacterial effects of novel silver nanoparticles". Journal of Nanotechnology. 2010. 18: 103-112.

[51] M. Mohsen, G. El- Santiel, H. Gaafar, H. El-Gendy, E. El-Beltagi, "Nutritional evaluation of berseem". Journal of Zootechnica, 2011.2 66-75.

[52] M. I. Husseiny, M. Abd El- Aziz, Y. Badr and M. A. Mahmoud Biosynthesis of Gold Nanoparticles Using Pseudomonas aeruginosa Spectrochim Acta A Mo Biomol Spectrosc 2006. 2007 67(3-4):1003 6

[53] D. S. Karaman S. Manner, A. Fallarero, and J. M. Rosenholm. Current Approaches for Exploration of Nanoparticles as Antibacterial Agents 2017. Antibacterial Agents, Ranjith N. Kumavath, Intech Open, DOI: $10.5772 / 68138$.

Dr Adetoyosi O. Daniels is a PhD Holder in Medical and pathogenic Microbiology from The Ekiti State University, Ado Ekiti, Ondo State, Nigeria. She was born in 1969 at Ile Oluji, Ondo State of Nigeria She has vast interest in medical research. She is currently the Dean of College of Natural and Applied Sciences of Achievers University formerly the Head of Department of Biological Sciences, Achievers University, Owo, Ondo State, Nigeria. Dr. Daniels also teaches undergraduate and post graduate courses in the department of Biological Sciences.

Dr Daniels is a member of The Nigerian Society for Microbiologist and Biotechnology Society of Nigeria.

Fadairo, J. K. is a Master's degree holder in Medical Laboratory Sciences of The Achievers University Owo. Specializing in Hematology. $\mathrm{He}$ is a member of the Medical Laboratory Science Council of Nigeria.

Fashoyin Aanu Oluwa is a research assistant attached to Dr A.O.Daniels in the Department of Biological Sciences, Achievers University, Owo, Ondo State, Nigeria. 